Artículo científico

(Original paper)

\title{
SPIDERS (ARACHNIDA: ARANEAE) OF THE TROPICAL MOUNTAIN CLOUD FOREST FROM EL TRIUNFO BIOSPHERE RESERVE, MEXICO
}

\author{
ARAÑAS (ARACHNIDA: ARANEAE) DEL BOSQUE MESÓFILO DE MONTAÑA DE LA \\ RESERVA DE LA BIOSFERA EL TRIUNFO, MÉXICO
}

\author{
EmMANuel Franco CAMPUZANO GRANADOS, GUILlERmo IBARRA NÚÑEZ*, José Francisco \\ GÓMEZ RODRÍGUEZ, GABRIELA GUADALUPE ANGULO ORDOÑES
}

El Colegio de la Frontera Sur, Unidad Tapachula, Carr. Antiguo Aeropuerto km. 2.5, Tapachula, Chiapas, C. P. 30700 , México. <ecampuzano@ecosur.edu.mx>; <gibarra@ecosur.mx>; <francisco.gomez.rdz@gmail.com>; <gaboinu@gmail.com>

*Autor de correspondencia: <gibarra@ecosur.mx>

Recibido: 09/10/2018; aceptado: 16/07/2019; publicado en línea: 13/08/2019

Editor responsable: Arturo Bonet Ceballos

Campuzano, E. F., Ibarra-Núñez, G., Gómez-Rodríguez, J. F., Angulo-Ordoñes, G. G. (2019) Spiders (Arachnida: Araneae) of the tropical mountain cloud forest from El Triunfo Biosphere Reserve, Mexico. Acta Zoológica Mexicana (nueva serie), 35, 1-19. https://doi.org/10.21829/azm.2019.3502092

\begin{abstract}
We carried out an intensive and systematized sampling of the spider fauna of the tropical mountain cloud forest (TMCF) in El Triunfo Biosphere Reserve, Chiapas, Mexico, in order to analyze their composition, species richness, abundance, and proportion of undescribed species, and to compare these results with those found in other TMCFs. We sampled ten plots in two seasons (dry and rainy) using different sampling techniques on two strata (ground and understory). A total of 7,432 specimens were collected corresponding to 28 families, 78 genera and 111 morphospecies. A high proportion of total species (58.6\%) were undescribed species. For 11 species originally described from a single sex, we found the other sex. Five species and one genus were new records for the Mexican spider fauna. Understory stratum had higher numbers of species and individuals than ground stratum, and there was a high species turnover, with only $17 \%$ of the total species shared between strata. The spider fauna of El Triunfo shows similarities with other TMCFs (especially that on the same mountain range) concerning the identities of dominant and species-rich families, family and genera composition, the presence and relevance (in abundance or richness) of families that are uncommon in lowland tropical habitats (Linyphiidae and Theridiosomatidae), and in the high proportion of undescribed species. However, there is a high species turnover among sites (only $16 \%$ species shared), even at relatively short distances, that seems derived in part from the relative high proportions of endemic species. Our results suggest that high abundance of Theridiosomatidae and Linyphiidae, together with high species richness of this last family, could be used as conservation indicators for the Mexican TMCFs. The high numbers of undescribed species in the analyzed TMCFs, and their relatively high endemicity levels, support that TMCFs could be regarded as hotspots for the order Araneae.
\end{abstract}

Key words: endemicity; ground spiders; species diversity; understory spiders; undescribed species 
Campuzano, E. F., Ibarra-Núñez, G., Gómez-Rodríguez, J. F., Angulo-Ordoñes, G. G. (2019) Las arañas (Arachnida: Araneae) del bosque mesófilo de montaña de la Reserva de la Biosfera El Triunfo, México. Acta Zoológica Mexicana (nueva serie), 35, 1-19. https://doi.org/10.21829/azm.2019.3502092

RESUMEN. Se realizó un muestreo intensivo y sistematizado de la araneofauna del bosque mesófilo de montaña (BMM) en la Reserva de la Biosfera El Triunfo, Chiapas, México, para analizar su composición, riqueza de especies, abundancia y proporción de especies no descritas, y para comparar estos resultados con los encontrados en otros BMMs. Se muestrearon diez parcelas en dos temporadas (secas y lluvias) empleando diferentes técnicas de muestreo sobre dos estratos (suelo y sotobosque). Se colectó un total de 7,432 especímenes, correspondientes a 28 familias, 78 géneros y 111 morfoespecies. Se encontró una alta proporción de especies no descritas (58.6\%). Para 11 especies descritas originalmente con un solo sexo, se encontró el otro sexo. Cinco especies y un género fueron nuevos registros para la araneofauna mexicana. El estrato del sotobosque presentó la mayor riqueza de especies y el mayor número de individuos respecto al estrato del suelo, y hubo un alto recambio de especies, con solo $17 \%$ del total de especies compartidas entre estratos. La araneofauna de El Triunfo muestra similitudes con otros BMMs (especialmente con uno de la misma cordillera) respecto a la identidad de las familias más ricas en especies y dominantes, así como en la composición de familias y géneros, la presencia y relevancia (en abundancia o riqueza) de familias que no son comunes en los hábitats tropicales de tierras bajas (Linyphiidae y Theridiosomatidae), y en la elevada proporción de especies no descritas. Sin embargo, se observó un alto recambio de especies entre sitios (solo $16 \%$ de especies compartidas), aún a distancias relativamente cortas, lo que parece ligado a proporciones relativamente altas de especies endémicas. Nuestros resultados sugieren que la alta abundancia de Theridiosomathidae y Linyphiidae, junto con la alta riqueza de especies de esta última familia, podrían ser empleadas como indicadores de conservación para los BMMs de México. El alto número de especies no descritas en los BMM analizados, y sus relativamente altos niveles de endemicidad, soportan la hipótesis de que los BMMs podrían ser considerados como posibles hotspot para el orden Araneae.

Palabras clave: arañas del sotobosque; arañas del suelo; diversidad de especies; endemismo; especies no descritas

\section{INTRODUCTION}

Spiders are animals with a wide array of adaptations that allowed them to colonize most of the terrestrial habitats and becoming a megadiverse order (Foelix, 2011). They rank in 7th place among the richest terrestrial animal groups (Coddington \& Levi, 1991), with more than 48,000 species (World Spider Catalog, 2019) and an estimated diversity of about 122,000 species (Agnarsson et al., 2013). Spiders have been evidenced as indicators of different types of environmental characteristics or alterations to the habitat that could be helpful to conservation purposes (Pozzi et al., 1998; Doran et al., 1999; Horváth et al., 2009; Buchholz, 2010; Cristofoli et al., 2010; Magura et al., 2010; Gerlach et al., 2013). However, the spider fauna is still poorly known for several regions of the world (Miller et al., 2014), and this is due in part to the reduced number of taxonomists, collections and to the relative difficulty to explore certain habitats (Coddington \& Levi, 1991; Jiménez, 1991). Indeed, the studies of spider fauna are very uneven among different habitats, as an example, the spider faunas of the tropical mountain cloud forests (TMCFs) had been studied only in a few countries, Peru (Silva, 1992), Indonesia (Russell-Smith \& Stork, 1994), Tanzania (Sorensen et al., 2002; Sorensen, 2003, 2004), Costa Rica (Yanoviak et al., 2003) and Mexico (Ibarra-Núñez et al., 2011; Maya-Morales et al., 2012; Méndez-Castro \& Rao, 2014; Campuzano et al., 2016).

In addition to the canopy, understory and soil levels of many forests, the TMCFs have a great abundance and diversity of epiphytes, in a high humidity environment, due to persistent presence of clouds, mist and high precipitation rates. TMCFs are known by harboring high levels of biodiversity in reduced 
areas (with high levels of endemism) and by the ecological services they offer to surrounding human populations. At the same time, TMCFs are among the most endangered habitats by direct human influence or by climatic change (Bubb et al., 2004, Sanchez-Ramos \& Dirzo, 2014). To preserve the diversity and ecological services of TMCFs, their species composition and their ecological dynamics are two basic subjects to study in view to stablish adequate management programs for this kind of habitats (Bubb et al., 2004).

North America is one of the best studied regions for spider diversity in the world (Coddington \& Levi, 1991; Ubick et al., 2017), however, knowledge about spiders is biased to the north (Canada, USA and north of Mexico) and to some vegetation types (Jiménez, 1991). The last published data about the number of spider species recorded from Mexico is about 2,158 (Ibarra-Núñez, 2013), a low value for a country known to be among the ten most biodiverse countries (Martínez-Meyer et al., 2014). Spiders from the Mexican TMCF have been barely explored, with the published studies including only a few localities: Tacaná volcano (Ibarra-Núñez et al., 2011; Maya-Morales et al., 2012), Xalapa (Méndez-Castro \& Rao, 2014) and El Triunfo (Campuzano et al., 2016). However, most of these publications do not include information about species composition or just give it partially and only one of these provide a complete list of the spiders found for one of the localities (Ibarra-Núñez et al., 2011). That publication showed that Linyphiidae was much more diverse (second in species richness) in the TMCF of Tacaná volcano than in other tropical sites (Silva, 1996; Silva \& Coddington, 1996; Hofer \& Brescovit, 2001). The Tacaná volcano study also included a high proportion of undescribed species from a variety of spider families (45.0\% of a total 151), suggesting that site as a possible biodiversity hotspot. Similar to those results, in the ground and understory of a TMCF in Tanzania, Sorensen et al. (2002) found $170 \mathrm{spp}$, of which about 80\% were undescribed, with Linyphiidae being third in species richness. As both studies were made on TMCFs, those data are indications that other sites with this vegetation type (as those in the Sierra Madre de Chiapas, Mexico) could have spider assemblages with similar patterns of composition, richness and high proportion of undescribed species.

This study aims to determine the spider fauna from the ground and understory (herbs, shrubs and small trees) of the TMCF in El Triunfo Biosphere Reserve (REBITRI for its Spanish acronym), Chiapas, Mexico, and to analyze if their spider species composition (i.e., species identities), richness and proportion of undescribed species are similar to those found in other TMCFs, including particularly a nearby site in the same mountain range, the Tacaná volcano (Ibarra-Núñez et al., 2011; Maya-Morales et al., 2012). In addition, new species records found at El Triunfo are included with their corresponding images. This study contributes to the knowledge of the biodiversity of a poorly studied and severely threatened habitat. The results found from these spiders' communities also could be useful in designing conservation strategies for the TMCFs of Mexico and Central America.

\section{MATERIALS AND METHODS}

Study area. The study site was located in El Triunfo Biosphere Reserve, Chiapas, Mexico (15' 39' 48.4'" to $15^{\circ} 38^{\prime} 54.3 \mathrm{~N}, 92^{\circ} 48^{\prime} 16.9^{\prime}$ ' to $92^{\circ} 48^{\prime} 38.5^{\prime \prime} \mathrm{W}, 1,998-2,115 \mathrm{~m}$ elevation, Fig. 1); this area comprises the largest and continuous cloud forest in Mexico (Pérez et al., 2010; Gual-Díaz \& Rendón-Correa, 2014). Climate in this region is temperate humid with a mean annual precipitation of 3,305 $\mathrm{mm}$ and a mean annual temperature of $14.7^{\circ} \mathrm{C}$ (CONAGUA, 2014). Dominant tree genera include species of Quercus, Matudea, Dendropanax, Ocotea, Conostegia, Amphitecna, Symplococarpon and Hedyosmum (Long \& Heath, 1991; Williams-Linera, 1991).

Field work and taxonomic determinations. Six sampling events were carried out (one per month) in 2014 over the two main seasons in the region, dry (from February to April) and rainy (from June to August). Ground and understory spiders were caught at each sampling event, in ten plots (each one $40 \times 16 \mathrm{~m}$ ) 
previously established around El Triunfo Camp which were separated by at least $100 \mathrm{~m}$ each. Difference in elevation between the highest and lowest plots was less than $100 \mathrm{~m}$. To access most of the spider fauna, we employed four collecting methods (modified from Coddington et al., 1991, Scharff et al., 2003 and Cardoso, 2009). For ground spiders, we used two sampling techniques per plot (Fig. 2): (1) eight pitfall-traps were distributed on both sides of the plot and recovered after 72 hours (each trap filled with $200 \mathrm{ml}$ of propylene glycol at $50 \%$ as preservative), and (2) four litter samples ( $1 \mathrm{~m}^{2}$ each one) were collected from each plot, to be examined (a few hours later) for the spiders. Understory spiders were sampled using two techniques in four circular subplots (5 m diameter, Fig. 2): (1) direct collect in two of the circular subplots, by hand or using an aspirator, investing in each subplot $15 \mathrm{~min}$ for low vegetation (from ground surface to knee level) and $15 \mathrm{~min}$ for high vegetation (from knee level to arm maximum reach), and (2) sweeping/beating vegetation for the other two subplots, using a sweep net for low vegetation (30 passes) and a stick with a 1 $\mathrm{m}^{2}$ collecting tray for high vegetation (30 strokes). Direct search and sweeping/beating were alternated each month to use both techniques in each subplot. Samplings were performed by four collectors at each sampling event.

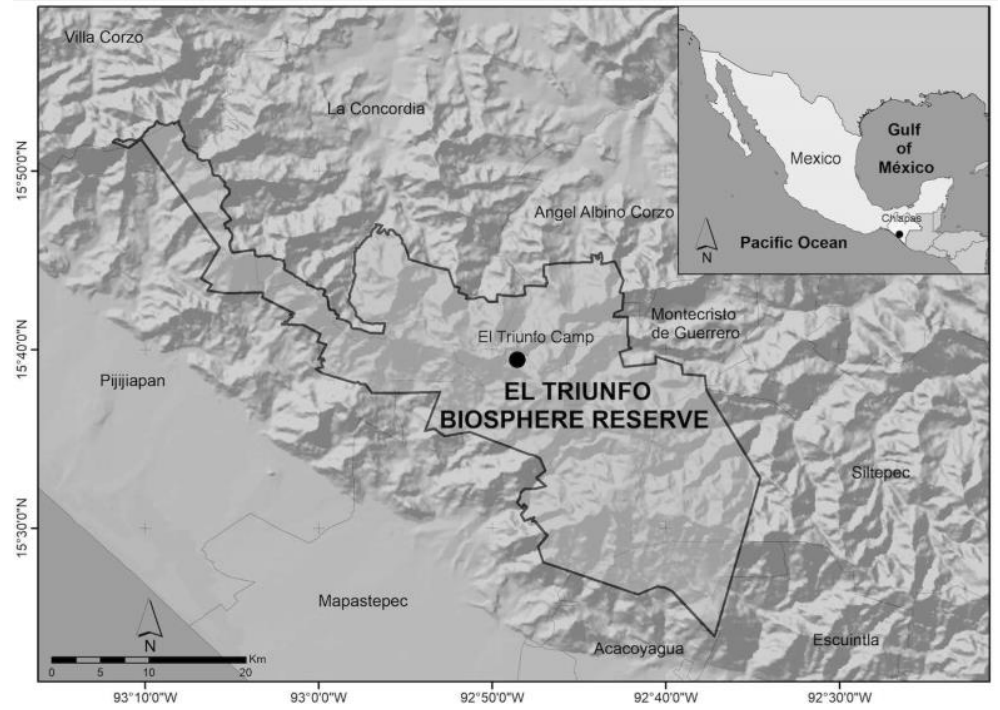

Figure 1. Location map of the study area in El Triunfo Biosphere Reserve, Chiapas, Mexico.

Collected spiders were preserved in 96\% ethanol and later deposited at the Colección de Arácnidos del Sureste de México (ECOTAAR) in El Colegio de la Frontera Sur, Tapachula, Chiapas, where they were identified to family, genus or species (or morphospecies) making use of taxonomic literature. Some too young immature specimens could not be identified below family rank, as their morphological characteristics did not allow us to do a good species assignment, these specimens were excluded from the species list, but not from the abundance results at family level. Other older immatures have enough characters to be determined to genus, and their association with species was made by comparing their somatic characters with those of adults, but when in doubt they also were excluded from the species list. All identified species and morphospecies were compared with the species recorded by Ibarra-Núñez et al. (2011), which are also deposited in ECOTAAR. Taxonomic classification follows the World Spider Catalog (2019) current arrangement, which also was the information source to detect the species not recorded previously in Mexico, these new records are supported in results with photographic images.

Data Analyses. Data analyses were carried out in R (R Development Core Team, 2018). Differences in species composition between strata (ground vs. understory) and localities (El Triunfo vs. Tacaná volcano) were evaluated using the Colwell and Coddington (1994) complementarity measure and Jaccard similarity index (Magurran, 2004). Colwell and Coddington measure (CC) varies from 0 (for an identical species composition) to 1 (for a completely different species composition), while the Jaccard index (SJ) varies 
inversely ( 0 for a completely different species composition and 1 for an identical species composition). In addition, Chao's estimated proportional similarity (CES, with 95\% confidence intervals) was calculated following Miller et al. (2014), who replace values in the Jaccard index with estimated values of Chao 1 shared species and ACE estimator values. SpadeR package was implemented to obtain these estimations (Chao et al., 2016).

Differences in species richness between strata and localities were tested by sample-size-based (i.e., standardized at the same number of individuals) and coverage-based (i.e., standardized at the same coverage) rarefaction/extrapolation curves (Chao et al., 2014). Sampling performance was evaluated by the coverage values obtained from such estimations. In addition, percentage of singletons, sampling intensity, completeness (i.e., observed species number as a percentage of the estimated species number based on the Chao 1 estimator; Magurran, 2004), percentage of undescribed species and rank of most species diverse and most abundant families were used to compare results from this study with results of Tacaná volcano (Chamé, 2011; Ibarra et al., 2011; Maya et al., 2012) and two other studies of spiders from cloud forests (Sorensen et al., 2002; Malumbres-Olarte et al., 2017).

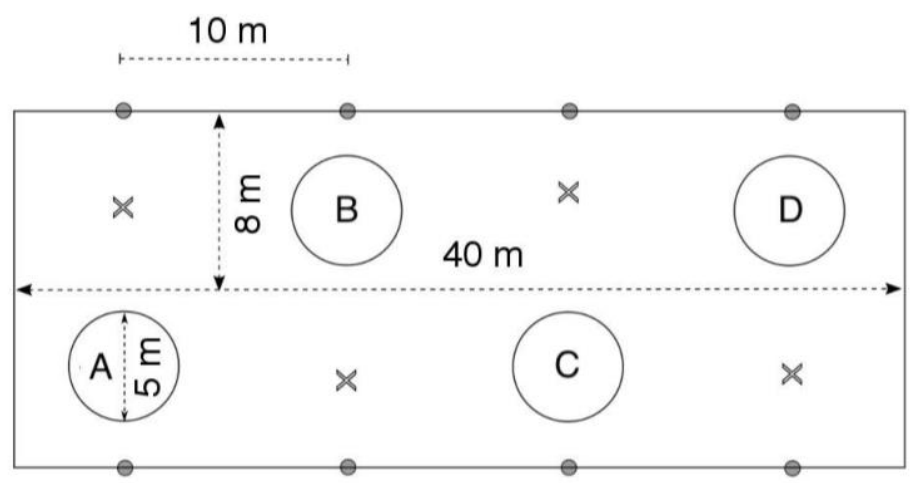

Figure 2. Sampling design implemented to collect ground and understory spiders associated to the tropical mountain cloud forest in El Triunfo Biosphere Reserve, Mexico. Ground spiders: pitfall-traps (gray circular dots) and litter ground samples (X marks). Understory spiders: direct search (2 circular subplots in one side of the plot) and sweeping/beating ( 2 circular subplots in the other side of the plot). See text for details.

\section{RESULTS}

El Triunfo overall results and new records. A total of 7,432 spiders were collected, 1,994 (26.8\%) and $5,438(73.2 \%)$ individuals from ground and understory, respectively. From that total 172 too young juveniles could not be assigned to a distinct species/morphospecies, but only to a family, so they were excluded from the species count (but not from the abundances count at family level). The collected specimens represent 28 families, 78 genera and 111 species/morphospecies, from which 41 were determined to species level, 12 as morphospecies related to a described species, 49 to genus, three to family and six were placed in a genus with doubt (Table 1). The 12 morphospecies related to a described species plus 47 of the morphospecies determined only to genus and the six species placed in a genus with doubt (58.6\% from total species) are considered undescribed species (65 in total).

Tetragnathidae was clearly the dominant family (2,666 individuals, 35.2\%), followed by Linyphiidae (1,711 individuals, 23\%), Theridiosomatidae (1,060 individuals, 14.3\%) and Theridiidae (723 individuals, 9.7\%) (Table 1, Fig. 3A). Theridiidae was the richest family (with 20 species, $18.2 \%$ ), followed by Linyphiidae (19 species, 17.3\%), Anyphaenidae and Tetragnathidae (nine species each, 8.2\%) and Araneidae and Salticidae (eight species each, 7.3\%), while the rest of families have no more than three species (Table 1, Fig. 3B). 
Table 1. Species list and abundances of spiders collected in the tropical mountain cloud forest from El Triunfo Biosphere Reserve, Mexico. G, ground stratum, U, understory stratum. SSt, sex-stage: $\partial$ adult male, $\varnothing$ adult female, I immature, $€$ sex undescribed, + species shared with Tacaná volcano, * new species record for Mexico. Species numeration is consecutive to that of Ibarra et al. (2011).

\begin{tabular}{|c|c|c|c|}
\hline \multirow{2}{*}{\multicolumn{4}{|c|}{ TAXA }} \\
\hline & & & \\
\hline Eratigena sp. 1 aff. E. flexuosa & 1 & - & $0^{\pi}$ \\
\hline Eratigena sp. 2 & 1 & - & $0^{2}$ \\
\hline Novalena sp. 2 & 89 & 16 & $0, q$ \\
\hline \multicolumn{4}{|l|}{ ANYPHAENIDAE } \\
\hline Anyphaena sp. 11 & - & 74 & 7 \\
\hline Anyphaena sp. 12 & - & 22 & $0^{\top}, q$ \\
\hline Anyphaena sp. 13 & - & 1 & 1 \\
\hline Anyphaena sp. 14 & - & 16 & 오 \\
\hline Anyphaena sp. 15 & - & 8 & 우 \\
\hline Anyphaena sp. 16 & - & 12 & $0^{1}$ \\
\hline Anyphaena sp. 17 & - & 1 & 7 \\
\hline Arachosia? sp. 1 & 3 & 4 & 우 \\
\hline Wulfila sp. 1+ & - & 2 & 오 \\
\hline \multicolumn{4}{|l|}{ ARANEIDAE } \\
\hline Araneus baul Levi, 1991 & - & 20 & $\jmath €$, \\
\hline Araneus sp. 3 & - & 76 & \\
\hline Araneus sp. 4 aff. A. guttatus & - & 1 & \\
\hline Araneus sp. 5 & - & 8 & \\
\hline Lewisepeira chichinautzin Levi, 1993+ & - & 21 & \\
\hline Manogea? sp. 1+ & - & 31 & \\
\hline Micrathena lenca Levi, 1985+ & 1 & 68 & $\jmath €$, q \\
\hline Ocrepeira rufa (O. Pickard-Cambridge, 1889)+ & - & 38 & 우 \\
\hline \multicolumn{4}{|l|}{ CLUBIONIDAE } \\
\hline Elaver sp. 2 & 2 & - & o, 오 \\
\hline Elaver sp. 3 & 2 & - & \\
\hline \multicolumn{4}{|l|}{ CORINNIDAE } \\
\hline Castianeira rica Reiskind, 1969 & - & 1 & $0^{\lambda}$ \\
\hline Megalostrata raptor (L. Koch, 1866)+ & - & 1 & 오 \\
\hline \multicolumn{4}{|l|}{ CTENIZIDAE } \\
\hline Ummidia sp. 1 aff. $U$. zebrina & 1 & - & 11 \\
\hline Ummidia sp. 2 & 1 & - & 0 \\
\hline \multicolumn{4}{|l|}{ DIPLURIDAE } \\
\hline Euagrus carlos Coyle, 1988 & 2 & - & q \\
\hline \multicolumn{4}{|l|}{ HAHNIIDAE } \\
\hline Amaloxenops? sp. 1 & 2 & - & o, 오 \\
\hline \multicolumn{4}{|l|}{ LINYPHIIDAE } \\
\hline Agyneta sp. 3 & 461 & 5 & \\
\hline Agyneta sp. 4 & 12 & - & \\
\hline Ceratinopsis sp. 2 & 158 & 2 & \\
\hline Fissiscapus sp. 2 & 82 & 4 & q \\
\hline Gonatoraphis? sp. 1 & 6 & - & \\
\hline Grammonota teresta Chickering, 1970+ & - & 4 & \\
\hline Jalapyphantes cuernavaca Gertsch \& Davis, 1946+ & 2 & 40 & $\hat{0}$, q \\
\hline Jalapyphantes puebla Gertsch \& Davis, 1946 & - & 29 & $\partial €$ \\
\hline Linyphia duplicata (F. O. Pickard-Cambridge, 1902)+ & - & 6 & $\phi €$ \\
\hline Linyphia linguatula (F. O. Pickard-Cambridge, 1902)+ & - & 1 & $\delta €$ \\
\hline Linyphia sp. $1+$ & - & 21 & $\mathrm{o}^{2}$, q \\
\hline Linyphia trifalcata (F. O. Pickard-Cambridge, 1902)* & 1 & 144 & $\hat{o}, \phi €$ \\
\hline Lygarina sp. 1 & 35 & - & $\hat{0}$, 우 \\
\hline Microctenonyx? sp. 1 & - & 3 & 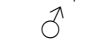 \\
\hline
\end{tabular}




\begin{tabular}{|c|c|c|c|}
\hline TAXA & G & $\mathbf{U}$ & SSt \\
\hline Paraletes sp. 3 aff. P. pogo & 22 & - & $\overline{0}$, 우 \\
\hline Selenyphantes longispinosus (O. Pickard-Cambridge, 1896)+ & - & 17 & o, 우 \\
\hline Sisis sp. 1 & 14 & 3 & $\hat{o}, q$ \\
\hline Toltecaria sp. 1 & 22 & - & $\sigma^{\lambda}, q$ \\
\hline Walckenaeria sp. 1 aff. W. crocea+ & 521 & 12 & $\hat{0}, q$ \\
\hline LIOCRANIDAE & & & \\
\hline Agroeca? sp. 1 & - & 17 & $\mathrm{I}$ \\
\hline MIMETIDAE & & & \\
\hline Mimetus sp. $1+$ & - & 4 & 0 \\
\hline MYSMENIDAE & & & \\
\hline Mysmena incredula (Gertsch \& Davis, 1936)* & 7 & 5 & 0 \\
\hline NESTICIDAE & & & \\
\hline Gaucelmus sp. 1 aff. G. strinatii & 1 & - & 0 \\
\hline OCHYROCERATIDAE & & & \\
\hline Ochyrocera machadoi (Gertsch, 1977) & 38 & - & $\hat{o}$, t \\
\hline Ochyrocera sp. 2 & 6 & - & $\hat{0}, q$ \\
\hline OONOPIDAE & & & \\
\hline Costarina plena (O. Pickard-Cambridge, 1894)+ & 60 & - & $\hat{0}, q$ \\
\hline Oonopidae sp. 2 & 2 & - & $\hat{0}, q$ \\
\hline Pescennina ibarrai Platnick \& Dupérré, 2011+ & 1 & 1 & q \\
\hline PARATROPIDIDAE & & & \\
\hline Paratropis sp. 1 & 4 & - & $0^{\pi}$ \\
\hline PHOLCIDAE & & & \\
\hline Ixchela pecki (Gertsch, 1971) & 3 & 2 & $0^{\lambda},+$ + \\
\hline Modisimus sp. 1 aff. M. propinquus & 10 & 7 & $\partial^{1},+9$ \\
\hline PHRUROLITHIDAE & & & \\
\hline Phonotimpus sp. 2 & 87 & - & $\hat{0}, q$ \\
\hline Phonotimpus sp. 3 & 33 & - & $\hat{o}, q$ \\
\hline Phonotimpus sp. 4 & 8 & - & 0 \\
\hline PRODIDOMIDAE & & & \\
\hline Tivodrassus sp. 1 & 1 & - & $0^{\pi}$ \\
\hline SALTICIDAE & & & \\
\hline Corythalia nigriventer (F. O. Pickard-Cambridge, 1901)* & - & 7 & q \\
\hline Cotinusa distincta (Pecham \& Peckham, 1888) & - & 9 & o \\
\hline Lyssomanes mexicanus Longunov, 2014 & - & 8 & $\delta, q €$ \\
\hline Mexigonus sp. 1+ & - & 127 & $\sigma^{\lambda}, q$ \\
\hline Phanias sp. 1 & - & 12 & $\hat{0}, q$ \\
\hline Salticidae sp. 1 & 1 & - & q \\
\hline Sarinda sp. 1 & - & 2 & $\sigma^{\pi}$ \\
\hline Zygoballus sp. 1 aff. Z. minutus & 1 & 56 & $\hat{0}, q$ \\
\hline TETRAGNATHIDAE & & & \\
\hline Azilia guatemalensis O. Pickard-Cambridge, 1889 & - & 5 & I \\
\hline Chrysometa rincon Levi, 1986 & 1 & 393 & $\delta €$, q \\
\hline Chrysometa sp. 1 aff. C. palenque+ & - & 68 & q \\
\hline Chrysometa sp. 3 & - & 5 & o \\
\hline Cyrtognatha sp. 1+ & - & 23 & $0^{\lambda}, q$ \\
\hline Glenognatha spherella Chamberlin \& Ivie, 1936+ & 3 & 243 & o, $q$ \\
\hline Leucauge simplex F. O. Pickard-Cambridge, 1903+ & - & 1767 & $0, q$ \\
\hline Leucauge sp. 2 & - & 110 & $0^{1}$ \\
\hline Tetragnatha sp. 1 & - & 3 & I \\
\hline THERAPHOSIDAE & & & \\
\hline Theraphosidae sp. 1 & 2 & - & 오 \\
\hline $\begin{array}{l}\text { THERIDIIDAE } \\
\text { Ameridion sp. } 2\end{array}$ & - & 24 & $\pi 0$ \\
\hline
\end{tabular}




\begin{tabular}{|c|c|c|c|}
\hline TAXA & G & $\mathbf{U}$ & SSt \\
\hline Ameridion sp. 3 aff. A. cobanum & - & 1 & o \\
\hline Ameridion sp. 4+ & - & 1 & q \\
\hline Chrosiothes sp. 1 aff. C. wagneri & - & 23 & $0^{\top}, q$ \\
\hline Cryptachaea sp. 1 & - & 1 & $0^{2}$ \\
\hline Exalbidion dotanum (Banks, 1914)+ & - & 3 & o \\
\hline Exalbidion rufipunctum (Levi, 1959)* & - & 3 & $\mathrm{O}^{\top}$, q \\
\hline Hentziectypus florens (O. Pickard-Cambridge, 1896)+ & - & 1 & q \\
\hline Neopisinus bigibbosus (O. Pickard-Cambridge, 1896)* & - & 10 & $\hat{0}$, 오 \\
\hline Phoroncidia triunfo Levi, 1964+ & - & 55 & $\jmath €$, 요 \\
\hline Phycosoma altum (Keyserling, 1886)+ & - & 15 & $\hat{0}, \underline{+}$ \\
\hline Phycosoma sp. 2 & - & 5 & $\hat{0}, 0$ \\
\hline Rhomphaea projiciens O. Pickard-Cambridge, 1896 & - & 18 & $\hat{0}$, ㅇ \\
\hline Spintharus flavidus Hentz, 1850+ & - & 13 & o, 우 \\
\hline Tekellina sp. 1 & - & 88 & $0^{\top}$ \\
\hline Theridion evexum Keyserling, 1884+ & - & 356 & $\hat{0}, q$ \\
\hline Theridula sp. 1 & - & 2 & I \\
\hline Thymoites sp. 4 aff. T. marxi & - & 13 & o, 우 \\
\hline Thymoites sp. 5 & - & 61 & $\hat{0}, 0$ \\
\hline Wirada mexicana Campuzano \& Ibarra-Núñez, 2018+ & - & 1 & $0^{2}$ \\
\hline \multicolumn{4}{|l|}{ THERIDIOSOMATIDAE } \\
\hline Epeirotypus sp. $1+$ & - & 665 & $\hat{0}$, o \\
\hline Theridiosoma davisi Archer, 1953+ & 20 & 372 & $\jmath €$, \\
\hline Wendilgarda mexicana Keyserling, 1886+ & - & 3 & 1 \\
\hline \multicolumn{4}{|l|}{ THOMISIDAE } \\
\hline Tmarus vitusus Chickering, 1956+ & - & 14 & $q €$ \\
\hline \multicolumn{4}{|l|}{ TRACHELIDAE } \\
\hline Trachelas sp. 1+ & 1 & 7 & o, 오 \\
\hline \multicolumn{4}{|l|}{ ULOBORIDAE } \\
\hline Philoponella tingens (Chamberlin \& Ivie, 1936)+ & - & 28 & $\mathrm{O}^{\lambda}, q$ \\
\hline Uloborus segregatus Gertsch, 1936+ & - & 1 & $0^{2}$ \\
\hline Uloboridae sp. 1 & - & 2 & I \\
\hline \multicolumn{4}{|l|}{ ZODARIIDAE } \\
\hline Ishania sp. 2 & 135 & - & $\mathrm{o}$, 우 \\
\hline Ishania sp. 3 & 22 & - & o, 우 \\
\hline Specimens not assigned to a morphospecies & 106 & 66 & I \\
\hline TOTAL & 1994 & 5438 & 7432 \\
\hline
\end{tabular}

One genus and five species were found as new records to Mexico. Lygarina Simon, 1894, new genus record, was cited previously only from South America (World Spider Catalog, 2018). The new species records were: Linyphia trifalcata (F. O. Pickard-Cambridge, 1902) (Figs. 4A-F) previously recorded from Guatemala, Mysmena incredula (Gertsch \& Davis, 1936) (Figs. 4G-L) from Bahamas, Cuba, Panama and USA, Neopisinus bigibbosus (O. Pickard-Cambridge, 1896) (Figs. 5A-J) and Corythalia nigriventer (F. O. Pickard-Cambridge, 1901) (Figs. 5K-N) both from Panama, and Exalbidion rufipunctum (Levi, 1959) (Figs. 6A-J) from Ecuador and Panama (World Spider Catalog, 2019) (Table 1). In addition, for 11 species originally described from a single sex, we found specimens from the other sex, seven males and four females from seven families: Araneidae, Linyphiidae, Salticidae, Tetragnathidae, Theridiidae, Theridiosomatidae and Thomisidae (Table 1).

Comparisons between ground and understory strata of El Triunfo. In the ground we found 22 families, 35 genera and 46 morphospecies, with Linyphiidae as the dominant family (1,405 individuals, 71.5\%), followed by Zodariidae (157 individuals, 7.9\%) and Phrurolithidae (128 individuals, 6.4\%) (Table 1, Fig. $3 \mathrm{~A})$; the richest family was Linyphiidae (12 species, 10.9\%) followed by Agelenidae, Oonopidae and 
Phrurolithidae (each with three species, 6.5\%) (Table 1, Fig. 3B). In the understory we found 17 families, 62 genera and 84 morphospecies, with Tetragnathidae as the dominant (2,645 individuals, $48.6 \%)$, followed by Theridiosomatidae (1,040 individuals, 19.1\%), Theridiidae (710 individuals, $13.1 \%)$ and Linyphiidae (306 individuals, 5.6\%) (Table 1, Fig. 3A). The richest family was Theridiidae (20 species, 24.1\%), followed by Linyphiidae (14 species, 16.9\%), Anyphaenidae and Tetragnathidae (nine species each, 10.8\%), Araneidae (eight species, 9.6\%) and Salticidae (seven species, 8.4\%) (Table 1, Fig. 3B). Both strata share 19 species, whereas 27 species were found only on the ground, and 65 species only on the understory (Table 1, Fig. 3B). The complementarity (CC) between these strata was 0.83 , while the SJ and CES values were 0.17 and $0.2(95 \%$ C. I. = lower 0.17, upper 0.43) respectively. Sample coverage were estimated at 99.3\% and $99.8 \%$ for the ground and understory strata, respectively. Understory stratum was significantly more species rich than ground stratum, both up to a standardized sample size (1.45 times richer at 3,776 individuals), as up to a standardized coverage (1.54 times richer at $99.8 \%$ of coverage) (Fig. 7A-B).
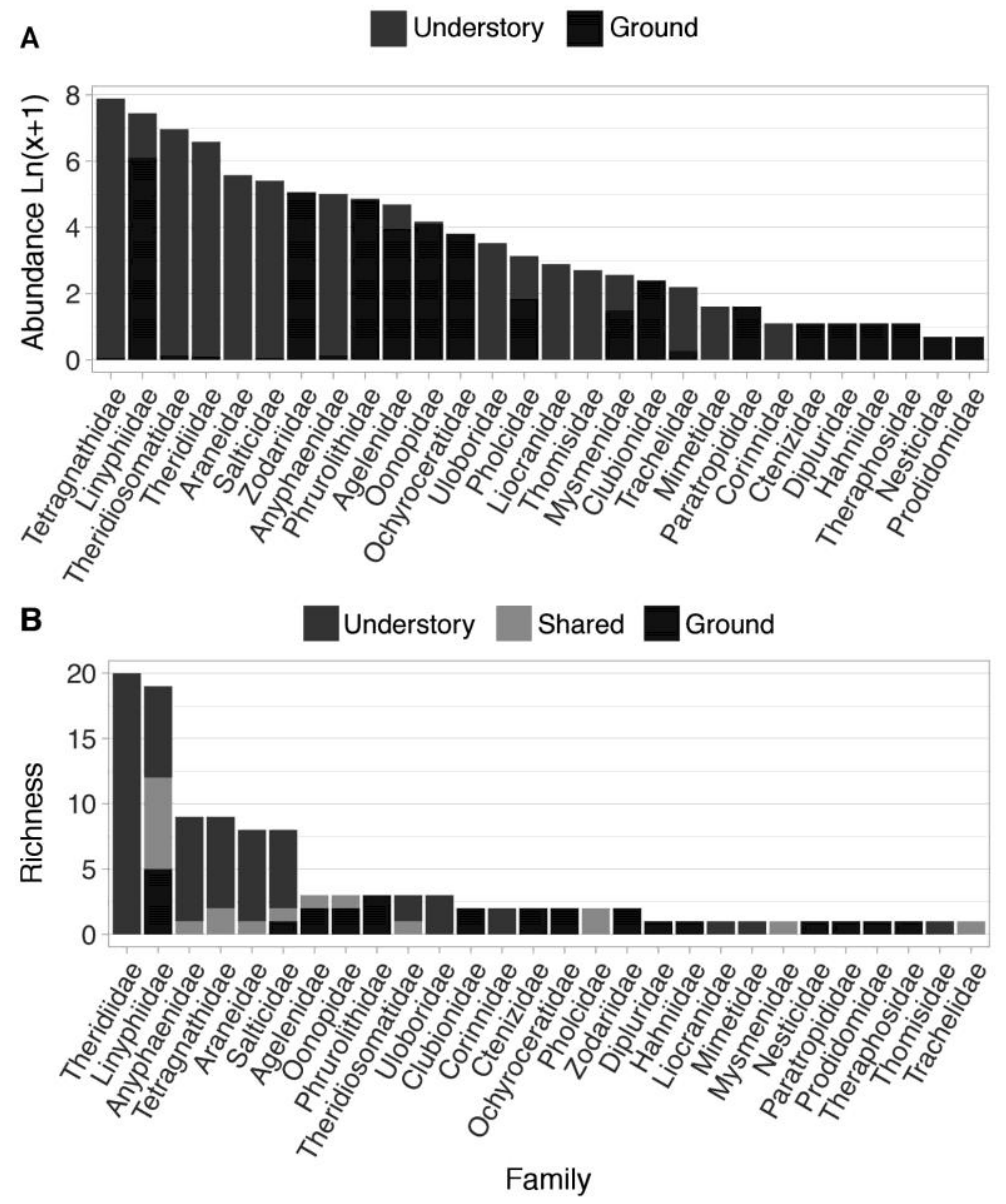

Figure 3. Abundance $(A, n=7,432)$ and species richness $(B, n=111)$ per family and stratum of spiders collected in the tropical mountain cloud forest from El Triunfo Biosphere Reserve, Mexico. Abundance is noted as Ln of the recorded abundance plus 1 to make visible those families with low abundance values.

Comparisons between El Triunfo and other TMCF sites. The Tacaná volcano study (Chamé, 2011; Ibarra et al., 2011; Maya et al., 2012) and the Sorensen et al. (2002) spiders' inventory of a Tanzanian TMCF have the most analogous data to be compared with those of this work (Table 2). The Uchumachi (Bolivia) site (cited in Malumbres-Olarte et al., 2017) is partially comparable by having only some of the same data types shown by the other studies. The sampling intensity (for adult specimens) for Tanzania was about 2.6, 3.7 
and 14.1 times of those of El Triunfo, Tacaná and Uchumachi, respectively, but the proportion of singletons and the completeness (empiric values) were similar for the Tanzanian and Mexican sites, whereas the Bolivian site had about twice of singletons percentage and the lowest completeness value. Concerning the proportion of undescribed species (empiric values), Tanzania had almost twice the value found in Tacaná and about 1.3 times the value for El Triunfo (Table 2). Theridiidae was the most species rich family in all three sites (there are no data for the Bolivian site), Linyphiidae occupied the second place in the Mexican sites and the third place in Tanzania. The dominant family was different in each site, but the subdominant was Linyphiidae in all three sites (there are no data for the Bolivian site) (Table 2).

For the Mexican sites, our results show that 36 spider species are shared between both sites, with 74 (67.3\%) exclusive species for El Triunfo and 115 (76.1\%) exclusive species for Tacaná volcano (Table 1 ), then the complementarity (CC) between both sites was 0.84 , while the SJ and CES values were 0.16 and 0.2 (95\% C. I. = lower 0.16, upper 0.41), respectively. At higher taxonomic levels, both sites shared 57 genera (113 genera for both sites) and 24 families ( 38 families for both sites). The families with more shared species between both sites were Theridiidae ( 8 species), Linyphiidae (7 species), Araneidae and Tetragnathidae (4 species each). From all shared species between both sites, 11 were undescribed species, thus, the number of endemic species for El Triunfo was 54 (65 total undescribed species minus 11 shared undescribed species with Tacaná volcano) corresponding to 48.6\%. of endemism. For the Tacaná volcano the number of endemic species is 52 (63 total undescribed species minus 11 shared undescribed species with El Triunfo) corresponding to $34.4 \%$ of endemism.

Sample coverages were estimated as $99.7 \%$ and $99.6 \%$ for El Triunfo and Tacaná volcano, respectively. Concerning the species richness, Tacaná volcano is significantly 1.34 times richer up to a standardized sample size (14,516 individuals) and for any estimated value of a sample size higher than 500 individuals (Fig. 7C). Similarly, Tacaná volcano is significantly 1.46 times richer up to a standardized coverage of $99.9 \%$. Both coverage-based curves show no overlapping for any observed or estimated values (Fig. 7D).

Table 2. Data on spiders' assemblages from studies of different Tropical Mountain Cloud Forest sites with comparable information. $(\mathrm{A}=$ Araneidae, $\mathrm{C}=$ Cyatholipidae, $\mathrm{G}=$ Tetragnathidae, $\mathrm{L}=$ Linyphiidae, $\mathrm{M}=$ Theridiosomatidae, $\mathrm{P}=$ Pholcidae, $\mathrm{S}=$ Salticidae, $\mathrm{T}=$ Theridiidae, $\mathrm{Y}=$ Anyphaenidae, $\mathrm{NA}=$ data not available). Source: 1) Malumbres-Olarte et al., 2017. 2) Sorensen et al. 2002. 3) Chamé, 2011; Ibarra-Núñez et al., 2011; Maya-Morales et al., 2012; IbarraNúñez data not published. 4) This study.

\begin{tabular}{|c|c|c|c|c|}
\hline Country / Site & $\begin{array}{c}\text { Bolivia / } \\
\text { Uchumachi }\end{array}$ & $\begin{array}{l}\text { Tanzania / } \\
\text { Uzungwa }\end{array}$ & $\begin{array}{c}\text { Mexico / } \\
\text { Tacaná }\end{array}$ & Mexico / Triunfo \\
\hline Abundance: All / Adults & NA / 579 & NA / 9,096 & $9,532 / 2,175$ & $7,260 / 2,273$ \\
\hline Sobs & 151 & 170 & 151 & 111 \\
\hline $\begin{array}{l}\text { Sampling intensity: } \\
\text { All / Adults }\end{array}$ & NA / 3.8 & $\mathrm{NA} / 53.5$ & $63.1 / 14.4$ & $66.0 / 20.7$ \\
\hline Singletons $(\%)$ & $64(42 \%)$ & $32(18.8 \%)$ & $29(19.2 \%)$ & $19(17.3 \%)$ \\
\hline $\begin{array}{l}\text { Estimated richness and } \\
\text { completeness (Chao1) }\end{array}$ & $214(71 \%)$ & $197(86 \%)$ & $186(81.2 \%)$ & $125(88.6 \%)$ \\
\hline Undescribed species $\%$ & NA & $80 \%$ & $41.7 \%$ & $58.6 \%$ \\
\hline $\begin{array}{l}\text { Rank of families for } \\
\text { species richness }\end{array}$ & NA & $\begin{array}{l}\mathrm{T}>\mathrm{S}>\mathrm{L}>\mathrm{A} \\
(35,17,13,8)\end{array}$ & $\begin{array}{c}\mathrm{T}>\mathrm{L}>\mathrm{A}=\mathrm{Y} \\
(29,20,14,14)\end{array}$ & $\begin{array}{c}\mathrm{T}>\mathrm{L}>\mathrm{Y}=\mathrm{G} \\
(20,19,9,9)\end{array}$ \\
\hline $\begin{array}{l}\text { Rank of families for } \\
\text { abundance }\end{array}$ & NA & $\mathrm{P}>\mathrm{L}>\mathrm{T}>\mathrm{C}$ & $\mathrm{T}>\mathrm{L}>\mathrm{Y}>\mathrm{G}$ & $\mathrm{G}>\mathrm{L}>\mathrm{M}>\mathrm{T}$ \\
\hline Source & 1 & 2 & 3 & 4 \\
\hline
\end{tabular}



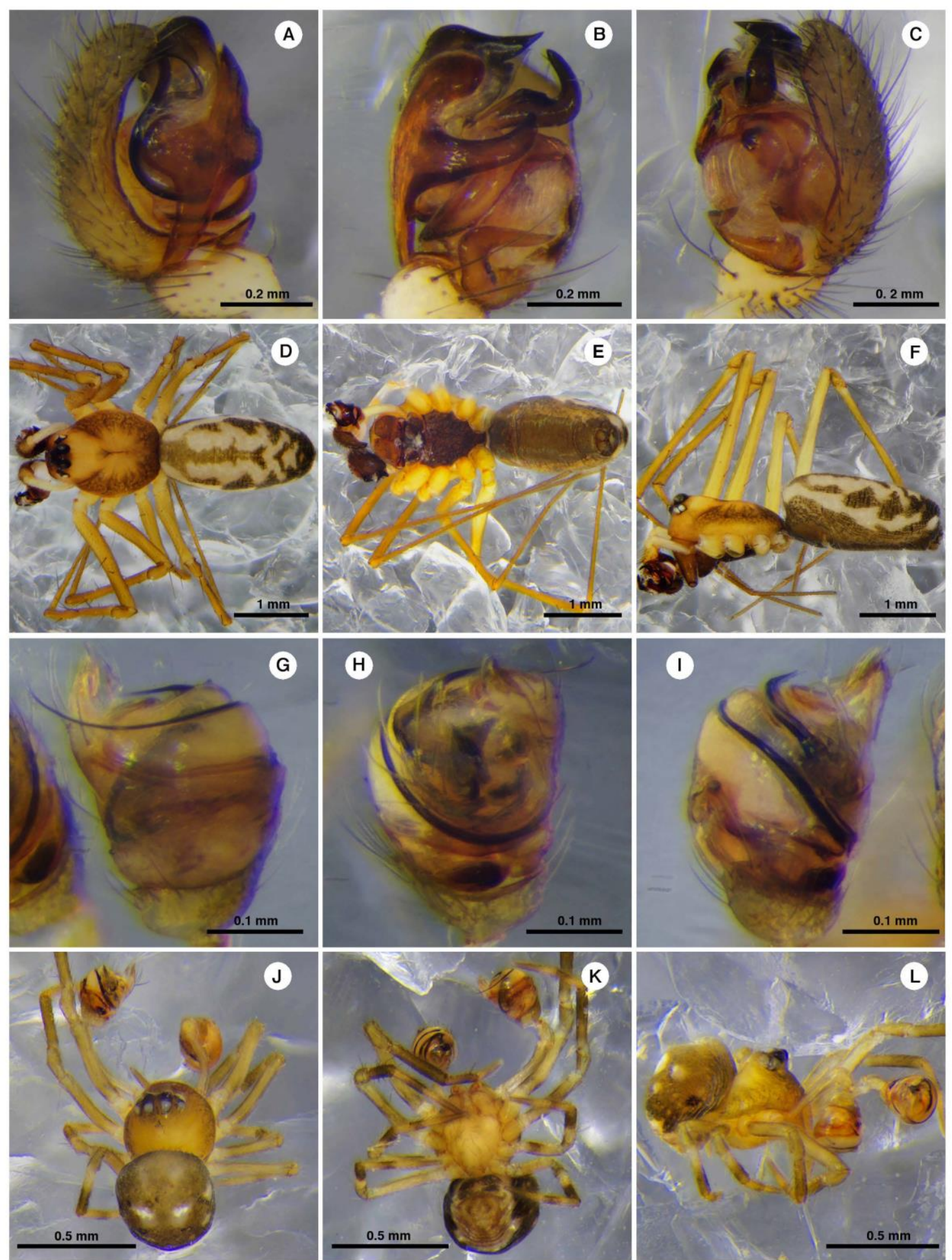

Figure 4. Males of Linyphia trifalcata (Linyphiidae) (A-F) and Mysmena incredula (Mysmenidae) (G-L). Left palpus in prolateral view $(A, G)$, left palpus in ventral view $(B, H)$, left palpus in retrolateral view $(C, I)$, habitus dorsal (D, J), habitus ventral $(\mathrm{E}, \mathrm{K})$ and habitus lateral $(\mathrm{F}, \mathrm{L})$. 


\section{DISCUSSION}

In El Triunfo there were clear differences between strata in species richness and composition, as confirmed by the rarefaction/extrapolation analyses (standardized values) and the low similarity values detected. Considering only exclusive species of each stratum (not standardized values), understory (65 species) was almost two times and a half as rich as the ground ( 27 species). If we consider all species, understory ( 84 species) was almost twice as rich as the ground (46 species). Differences in number of specimens between strata followed a similar pattern. Nevertheless, there was a slightly higher number of families on the ground, but only about half of genera than the understory. The distribution of the undescribed species between strata also follows this pattern, as 33 undescribed species were collected only on the understory, 22 only on the ground and 10 on both strata.
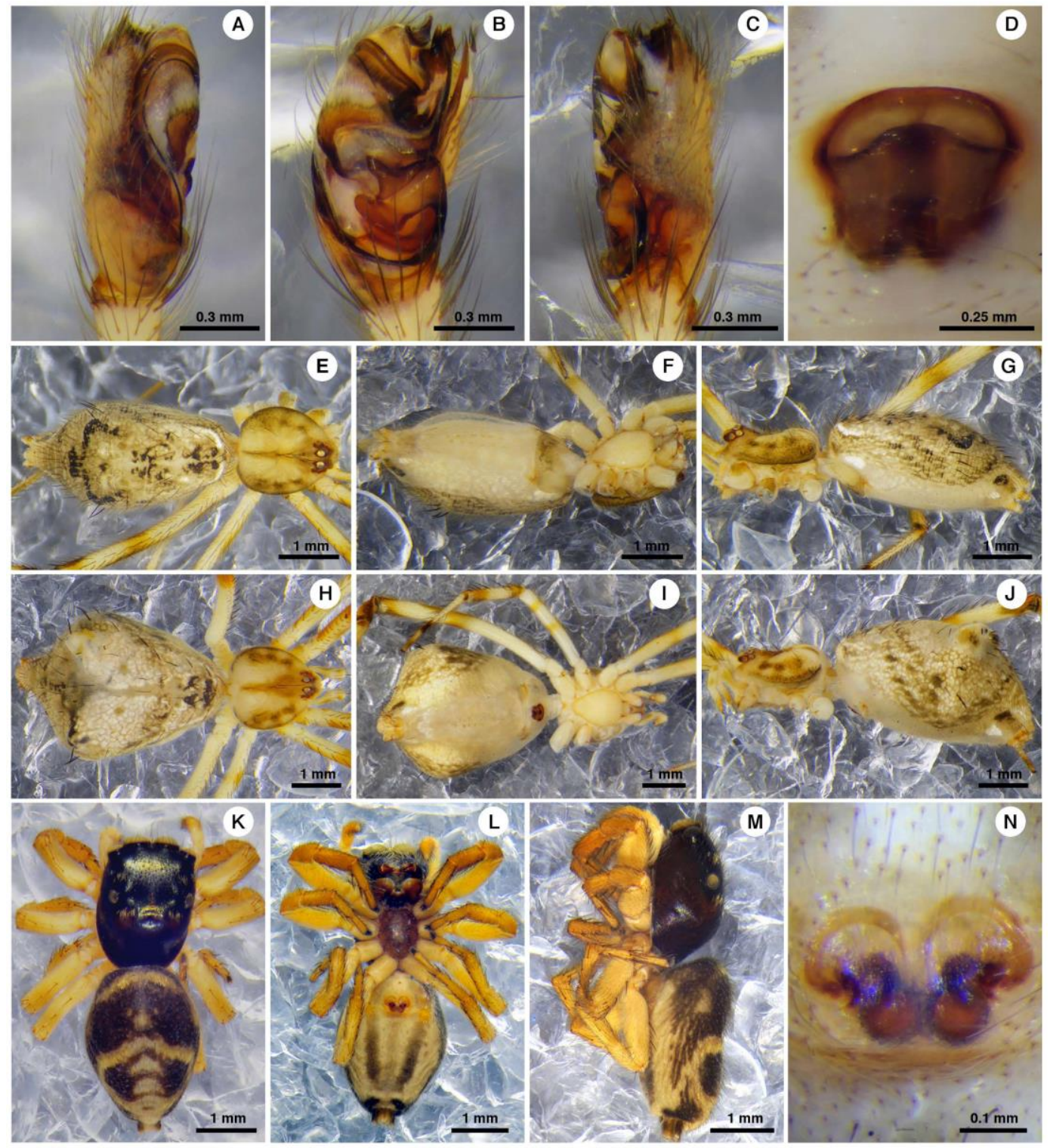

Figure 5. Neopisinus bigibbosus (Theridiidae) (A-J) and Corythalia nigriventer (Salticidae) (K-N). Male (A-C, E$\mathrm{G})$, female (D, H-N). Left palpus in prolateral view (A), left palpus in ventral view (B), left palpus in retrolateral view (C), epigynum in ventral view $(\mathrm{D}, \mathrm{N})$, habitus dorsal $(\mathrm{E}, \mathrm{H}, \mathrm{K})$, habitus ventral $(\mathrm{F}, \mathrm{I}, \mathrm{L})$, habitus lateral $(\mathrm{G}, \mathrm{J}$, 
The higher species richness on the understory could be derived, in part from differences in sampling effort (number of specimens), but also from a higher number of available microhabitats on the understory, due to a more complex habitat (with high diversity of herbs, shrubs and epiphytes) that make possible the cohabitation of a greater number of species (Greenstone, 1984; Halaj et al., 2000). This pattern of higher species number on the understory vs. the ground agrees with other spider surveys in TMCF (Sorensen et al., 2002; Sorensen, 2003; Ibarra-Núñez et al., 2011). Differences in species composition between strata are shown in the high observed and estimated species turnover values. An intermediate complementarity value between ground and understory $(\mathrm{CC}=0.58)$ was previously mentioned for another cloud forest from Tanzania (Sorensen, 2003), but the corresponding values found in our study (0.83) and in another locality in the same mountain range (0.76) by Ibarra-Núñez et al. (2011), suggest greater environmental and/or structural differences between these strata for the Mexican TMCFs, resulting in a noticeable vertical stratification.
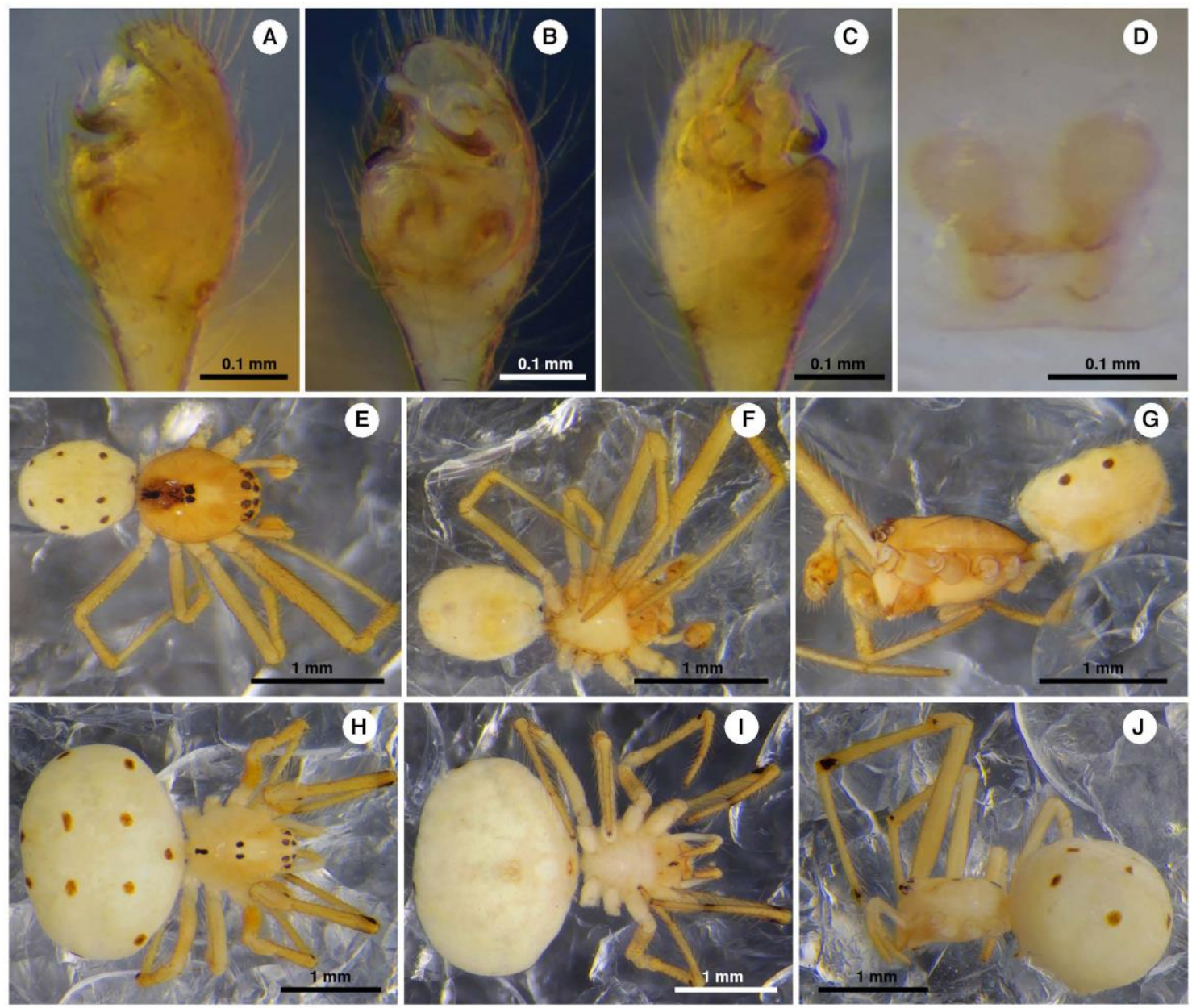

Figure 6. Exalbidion rufipunctum (Theridiidae), male (A-C, E-G), female (D, H-J). Left palpus in prolateral view (A), left palpus in ventral view (B), left palpus in retrolateral view (C), epigynum in ventral view (D), habitus dorsal $(\mathrm{E}, \mathrm{H})$, habitus ventral $(\mathrm{F}, \mathrm{I})$, habitus lateral $(\mathrm{G}, \mathrm{J})$.

Tacaná volcano is located on the Sierra Madre de Chiapas, just $98 \mathrm{~km}$ away from El Triunfo (IbarraNúñez et al., 2011; Maya-Morales et al., 2012). This relatively short distance generated the expectation that the TMCFs on both sites could share a high proportion of spider species. Nevertheless, the complementarity/similarity values found between both sites shown low similarity at species level, but at 
genus and family level, the higher proportions of shared taxa $(50.4 \%$ of total genera and $63.2 \%$ of total families) show a probably ancient community shared between these sites. The levels of endemism for both sites are comparable to other groups that inhabit the TMCFs of Mexico, like plants and mammals (SánchezRamos \& Dirzo, 2014), but lower to that found for reptiles and amphibians (Gual-Díaz \& MayerGoyenechea, 2014, Mayer-Goyenechea \& Gual-Díaz, 2014) and even for Mexican spiders in another habitat (Rivera-Quiroz et al., 2016). These values could be reduced if in future surveys some of these endemic species are found to be present in other sites. The high species turnover between sites seems due in great part to the observed relatively high proportions of endemics species.
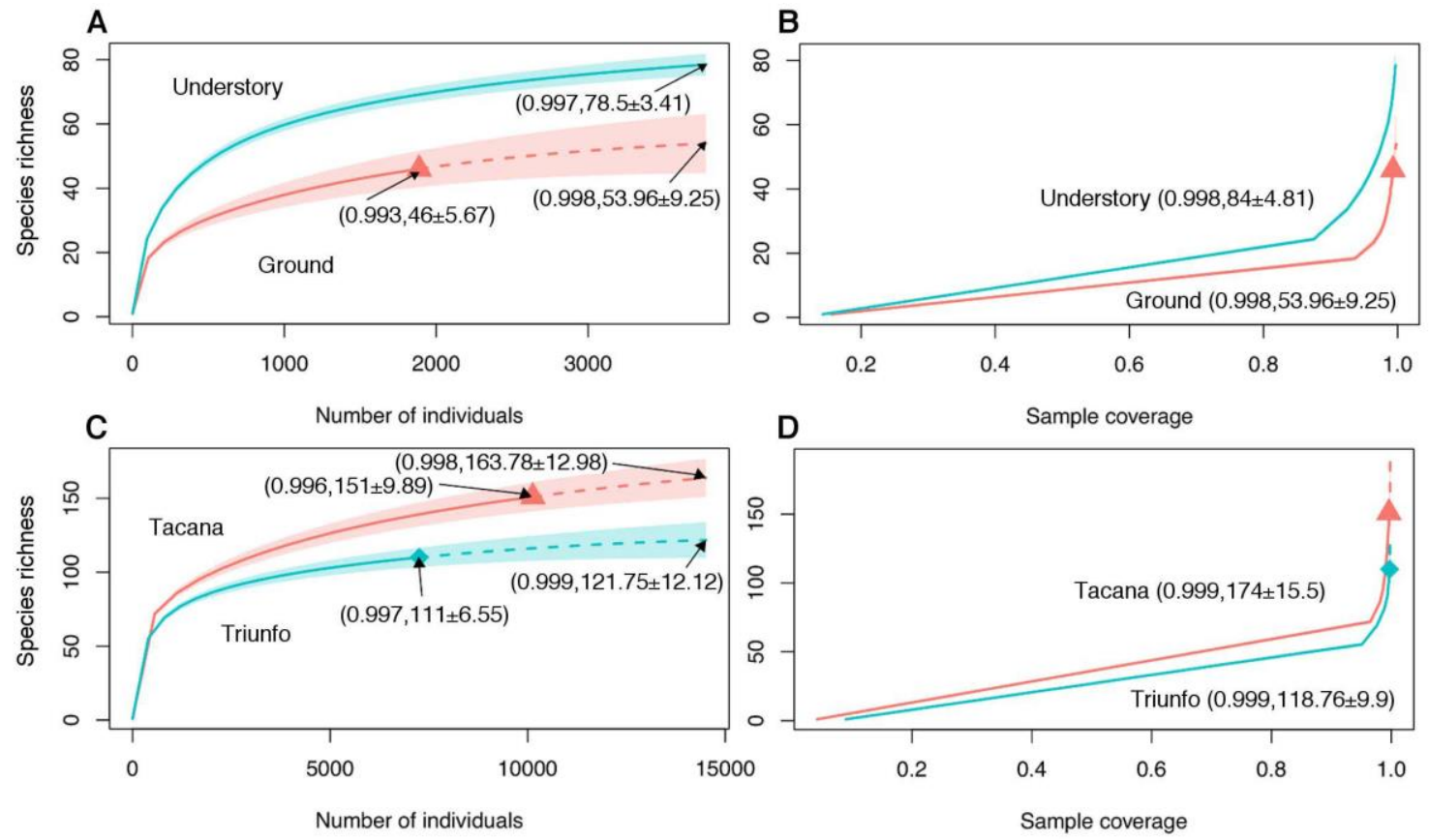

Figure 7. Spider species richness comparison between ground and understory strata of the tropical mountain cloud forest from El Triunfo Biosphere Reserve (A-B), and between El Triunfo and Tacaná volcano localities (C-D).

Comparisons based on Chao et al. (2014) methodology using sample-size-based (A, C) and coverage-based (B, D) rarefaction (solid lines) and extrapolation (dashed lines) curves, with 95\% confidence intervals (gray-shaded regions). Sample-size curves constructed up to the base sample size (i.e., twice the smaller sample). Coverage-based curves (B, D) calculated over the higher coverage percentage of each comparison. Reference samples (when displayed) are denoted by a different polygon for each curve in each comparison. Numbers in parentheses indicate the sample coverage with their respective richness values and confidence interval at each sample reference and /or comparison level.

Concerning the observed species richness, in both sites Theridiidae and Linyphiidae were the two most species rich families, followed by Anyphaenidae, Araneidae and Salticidae. The families Araneidae and Theridiidae are the two most diverse in many tropical habitats (Silva, 1996; Silva \& Coddington, 1996; Ibarra-Núñez \& García-Ballinas, 1998; Höfer \& Brescovit, 2001; Ibarra-Núñez, 2013). Our results corroborate Theridiidae as highly diverse in both sites, but Araneidae was only moderately diverse, having the fifth/sixth place (shared with Salticidae). On the contrary, the occurrence of Linyphiidae among the richest families is common for temperate regions (Paquin \& Dupérré, 2003; Ubick et al., 2017), but is atypical for tropical habitats, except for some tropical mountain faunas, where this family becomes more diverse (Silva, 1992; Sorensen, 2003; Ibarra-Núñez et al., 2011). It was notorious that Theridiosomatidae was the only family to share all its three species between both sites. Theridiosomatids are known to inhabit mostly in "humid, shaded forest habitats" (Coddington, 1986) as are these cloud forests, highlighting their potential as indicator species of this kind of habitats. Our results suggest that some Linyphiidae species (and 
perhaps also some Theridiosomatidae species) are taking the place of some Araneidae from tropical lowlands. Similar data were found by Russell and Stork (1994) and Sorensen (2004) in Indonesia and Tanzania, respectively. However, more studies about the distributional patterns for these families are necessary to support this hypothesis. Our results suggest that a high abundance of Theridiosomatidae and Linyphiidae, and a high species richness of Linyphiidae, are indicators of a good conservation level for the Mexican TMCFs. It is also interesting that several genera collected in both sites in Mexico (Fissiscapus, Paraletes, Wirada) or only in one of these sites (Sidymella, Josa, Lygarina) were found previously only in South America (World Spider Catalog, 2019), suggesting some affinities with the fauna from that subcontinent. A similar pattern has been recorded for some tree species in this type of forests (Rzedowski, 1996; Gual-Díaz \& Rendón-Correa, 2014).

High proportions of undescribed spider species in tropical habitats have been cited previously (Coddington \& Levi, 1991; Sorensen, 2003; Coddington et al., 2009; Miller et al., 2014). Data from different sites, with many undescribed species are not easily comparable in terms of taxonomic composition. Miller et al. (2014) have suggested as a possible solution what they call "Cyberdiversity", an online communitybased approach to compare results (specimens) from independent inventories with incomplete taxonomic knowledge by means of photographic images and/or DNA barcodes. Miller et al. (2014) and Rivera-Quiroz et al. (2016) consider that Cyberdiversity can overcome the taxonomic impediment and accelerate the comparison of specimens at distance, allowing to contrast faunal inventories (even without a name), making possible to know the distribution range of particular species, and enabling the detection of possible new species by taxonomists. We agree with this initiative, as we know it effectively enhance the taxonomic study and comparison of spider faunas. For a new species recently described by Campuzano and Ibarra-Núñez (2018) that was found first in four localities of Chiapas, the access to the images of the Diversity Inventory Pages by Álvarez-Padilla (2017) allowed the authors to know that this species was also found in San Luis Potosí (about 1,000 km away).

The proportions of undescribed species for each site (59\% for El Triunfo, 54\% for Tacana volcano) show a similar pattern between both sites, with more than half of observed species as new to science. The proportions of potential endemic species (new species for each site minus shared new species) is also high, 48\% for El Triunfo, 47\% for Tacana volcano. These data and those of Sorensen et al. (2002) showed a high proportion of undescribed species (potential endemic species), give support to the idea that TMCFs are hotspots of diversity for spiders. In spite of the high level in species turnover between the spiders' assemblages of El Triunfo and Tacana volcano, both have similarities concerning the identity of the families with most species richness, in the families and genera composition, and in the proportions of undescribed species. The latter and the findings of the undescribed sex of several species, highlights the importance to carry out more studies on the spider fauna to better known their true diversity in this kind of habitats.

ACKNOWLEDGMENTS. We would thank Héctor Montaño (ECOSUR) for the assistance in collecting specimens. Thanks to Miriam Janette González García and rangers Ismael, Edilberto, Ramiro and Enelfo (REBITRI) for the logistic support in the Biosphere Reserve. Collect permit was provided by the Secretaría de Medio Ambiente y Recursos Naturales (SEMARNAT: SGPA/DGVS/00329/14) to G. Ibarra-Núñez. The Consejo Nacional de Ciencia y Tecnología (CONACYT), México supported this project with a grant (179476) to G. Ibarra-Núñez and fellowships to E. F. Campuzano, J. F. Gómez and G. G. Angulo.

\section{LITERATURE CITED}

Agnarsson, I., Coddington, J. A., Kuntner, M. (2013) Systematics, pp. 58-11. In: Penney, D. (Ed.). Spider research in the 21 st century, trends and perspectives. Siri Scientific Press, UK, Manchester.

Alvarez-Padilla Laboratory (2017) Biodiversity of Araneomorphae from Mexico. Facultad de Ciencias, 
UNAM. Available at: www.unamfcaracnolab.com (accessed on May 2019).

Bubb, P., May, I., Miles, L., Sayer, J. (2004) Cloud forest agenda. UNEP-WCMC. Cambridge, UK, 32 pp.

Buchholz, S. (2010) Ground spider assemblages as indicators for habitat structure in inland sand ecosystems. Biodiversity and Conservation, 19, 2565-2595. https://doi.org/10.1007/s10531-010-9860-7

Campuzano, E. F., Ibarra-Núñez, G. (2018) A new species of the spider genus Wirada (Araneae, Theridiidae) from Mexico, with taxonomic notes on the genus and a key to the species. Zootaxa, 4457 (3), 495-500. https://doi.org/10.11646/zootaxa.4457.3.13

Campuzano, E. F., Ibarra-Núñez, G., Chamé-Vázquez, E. R., Montaño-Moreno, H. (2016) Understory spider assemblages from a cloud forest in Chiapas, Mexico, and their relationships to environmental variables. Arthropod-Plant Interactions, 10, 237-248.

https://doi.org/10.1007/s11829-016-9426-z

Cardoso, P. (2009) Standardization and optimization of arthropod inventories - the case of Iberian spiders. Biodiversity and Conservation, 18, 3949-3962. http://doi.org/10.1007/s10531-009-9690-7

Chamé Vázquez, D. (2011) Arañas de suelo del bosque mesófilo de montaña, conservado y alterado en el Soconusco, Chiapas, México. Tesis de Licenciatura en Biología. Universidad de Ciencias y Artes de Chiapas, Tuxtla Gutiérrez, Chiapas. 66 pp.

Chao, A., Gotelli, N. J., Hsieh, T. C., Sander, E. L., Ma, K. H., Colwell, R. K., Ellison, A. M. (2014) Rarefaction and extrapolation with Hill numbers: a framework for sampling and estimation in species diversity studies. Ecological Monographs, 84, 45-67. http://doi.org/10.1890/13-0133.1

Chao, A., Ma, K. H., Hsieh, T. C., Chiu, C. H. (2016) Online Program SpadeR (Species-richness, Prediction And Diversity Estimation in R). Available at: http://chao.stat.nthu.edu.tw/wordpress/software_download (accessed on May 2019).

Coddington, J. A. (1986) The genera of the spider family Theridiosomatidae. Smithsonian Contributions to Zoology, 422, 1-96. http://doi.org/10.5479/si.00810282.422

Coddington, J. A., Levi, H. W. (1991) Systematics and evolution of spiders (Araneae). Annual Review of Ecology and Systematics, 22, 565-592.

Coddington, J. A., Griswold, C. E., Silva Davila, D., Peñaranda, E., Larcher, S. F. (1991) Designing and testing sampling protocols to estimate biodiversity in tropical ecosystems, pp 44-46. In: Dudley, E. C. (Ed.). The unity of evolutionary biology, Vol. 1. Proceedings of the Fourth International Congress of Systematics and Evolutionary Biology. Dioscorides Press, Portland, Oregon, USA.

Coddington, J. A., Agnarsson, I., Miller, J. A., Kuntner, M., Hormiga, G. (2009) Undersampling bias: the null hypothesis for singleton species in tropical arthropod surveys. Journal of Animal Ecology, $78,573-584$.

http://doi.org/10.1111/j.1365-2656.2009.01525.x

Colwell, R., Coddington, J. (1994) Estimating terrestrial biodiversity through extrapolation. Philosophical Transactions of the Royal Society: B: Biological Sciences, 345, 101-118. https://doi.org/10.1098/rstb.1994.0091

Comisión Nacional del Agua (CONAGUA) (2014) Archivos de la Dirección Técnica: Datos de la estación meteorológica automática El Triunfo. Centro Hidrometeorológico Regional “Tuxtla Gutiérrez”. Tuxtla Gutiérrez, Chiapas.

Cristofoli, S., Mahy, G., Kekenbosch, R., Lambeets, K. (2010) Spider communities as evaluation tools for wet heathland restoration. Ecological Indicators, 10, 773-780. http://doi.org/10.1016/j.ecolind.2009.11.013.

Doran, N. E., Kiernan, K., Swain, R., Richardson, A. M. M. (1999) Hickmania troglodytes, the Tasmanian cave spider, and its potential role in cave management. Journal of Insect Conservation, 
3, 257-262.

Foelix, R. F. (2011) Biology of spiders (3rd ed.). Oxford University Press. USA, New York, 419 pp.

Gerlach, J., Samways, M., Pryke, J. (2013) Terrestrial invertebrates as bioindicators: an overview of available taxonomic groups. Journal of Insect Conservation, 17, 831-850. http://doi.org/10.1007/s10841-013-9565-9.

Greenstone, M. H. (1984) Determinants of web spider species diversity: vegetation structural diversity vs. prey availability. Oecologia, 62 (3), 299-304. http://doi.org/10.1007/BF00384260

Gual-Díaz, M., Mayer-Goyenechea, I. G. (2014) Anfibios en el bosque mesófilo de montaña en México, pp. 249-262. In: Gual-Díaz, M., Rendón-Correa, A. (Eds.). Bosques mesófilos de montaña de México: diversidad ecología y manejo. Comisión Nacional para el Conocimiento y Uso de la Biodiversidad, México, Ciudad de México.

Gual-Díaz, M., Rendón-Correa, A. (2014) Bosques mesófilos de montaña de México: diversidad, ecología y manejo. Comisión Nacional para el Conocimiento y Uso de la Biodiversidad. México, Ciudad de México, 352 pp.

Halaj, J., Ross, D. W., Moldenke, A. R. (2000) Importance of habitat structure to the arthropod food-web in Douglas-fir canopies. Oikos, 90, 139-152. http://doi.org/10.1034/j.1600-0706.2000.900114.x

Höfer, H., Brescovit, A. D. (2001) Species and guild structure of a Neotropical spider assemblage (Araneae) from Reserva Ducke, Amazonas, Brazil. Andrias, 15, 99-119.

Horváth, R., Magura, T., Szinetár, C., Tóthmérész, B. (2009) Spiders are not less diverse in small and isolated grasslands, but less diverse in overgrazed grasslands: A field study (East Hungary, Nyírség). Agriculture, Ecosystems and Environment, 130, 16-22.

http://doi.org/10.1016/j.agee.2008.11.011

Ibarra-Núñez, G. (2013) Diversidad de las arañas (Arachnida: Araneae), pp. 191-196. In: Comisión Nacional para el Conocimiento y Uso de la Biodiversidad (Ed.). La biodiversidad en Chiapas: Estudio de Estado. Vol. 2. Comisión Nacional para el Conocimiento y Uso de la Biodiversidad, Gobierno del Estado de Chiapas, México, Ciudad de México.

Ibarra-Núñez, G., García-Ballinas, J. A. (1998) Diversidad de tres familias de arañas tejedoras (Araneae: Araneidae, Tetragnathidae, Theridiidae) en cafetales del Soconusco, Chiapas, México. Folia Entomológica Mexicana, 102, 11-20.

Ibarra-Núñez, G., Maya-Morales, J., Chamé-Vázquez, D. (2011) Las arañas del bosque mesófilo de montaña de la Reserva de la Biosfera Volcán Tacaná, Chiapas, México. Revista Mexicana de Biodiversidad, 82, 1183-1193.

Jiménez, M. L. (1991) Araneae, pp. 83-101. In: Llorente, J., García, A., Gonzáles, E. (Eds.). Biodiversidad, taxonomía y biogeografía de artrópodos de México: hacia una síntesis de su conocimiento. Vol. 1. Instituto de Biología, Universidad Nacional Autónoma de México, México, Ciudad de México.

Long, A. H., Heath, M. (1991) Flora of the El Triunfo Biosphere Reserve, Chiapas, México: a preliminary floristic inventory and the plant communities of polygon I. Anales del Instituto de Biología, Universidad Nacional Autónoma de México, Serie Botánica, 62, 133-172.

Magura, T., Horváth, R., Tóthmérész, B. (2010) Effects of urbanization on ground-dwelling spiders in forest patches, in Hungary. Landscape Ecology, 25, 621-629. http://doi.org/10.1007/s10980-009-9445-6

Magurran, A. E. (2004) Measuring Biological Diversity. Blackwell Science. Oxford, UK, 256 pp.

Malumbres-Olarte, J., Scharff, N., Pape, T., Coddington, J. A., Cardoso, P. (2017) Gauging megadiversity with optimized and standardized sampling protocols: A case for tropical forest spiders. Ecology and Evolution, 7, 494-506.

http://doi.org/10.1002/ece3.2626

Martínez-Meyer, E., Sosa-Escalante, J. E., Álvarez, F. (2014) El estudio de la biodiversidad en México: ¿una ruta con dirección? Revista Mexicana de Biodiversidad, 85, S1-S9. 
Maya-Morales, J., Ibarra-Núñez, G., León-Cortés, J. L., Infante, F. (2012) Understory spider diversity in two remnants of tropical montane cloud forest in Chiapas, Mexico. Journal of Insect Conservation, 16 (1), 25-38. https://doi.org/10.1007/s10841-011-9391-x

Mayer-Goyenechea, I. G., Gual-Díaz, M. (2014) Reptiles en el bosque mesófilo de montaña en México, pp. 263-278. In: Gual-Díaz, M., Rendón-Correa, A. (Eds.). Bosques mesófilos de montaña de México: diversidad, ecología y manejo. Comisión Nacional para el Conocimiento y Uso de la Biodiversidad, México, Ciudad de México.

Méndez-Castro, F. E., Rao, D. (2014) Spider diversity in epiphytes: Can shade coffee plantations promote the conservation of cloud forest assemblages? Biodiversity and Conservation, 23 (10), 2561-2577. https://doi.org/10.1007/s10531-014-0739-x

Miller, J. A., Miller, J. H., Pham, D.-S., Beentjes, K. K. (2014) Cyberdiversity: improving the informatic value of diverse tropical arthropod inventories. PLOS ONE, 9 (12), e115750. http://dx.doi.org/10.1371/journal.pone.0115750

Paquin, P., Duperré, N. (2003) Guide d'identification des Araignées (Aranae) du Québec. Fabreries, Supplement, 11, 1-251.

Pérez, M., Tejada, C., Silva, E. (2010) Los bosques mesófilos de montaña en Chiapas: situación actual, diversidad y conservación. Universidad de Ciencias y Artes de Chiapas. México, Tuxtla Gutiérrez, $330 \mathrm{pp}$.

Pozzi, S., Gonseth, Y., Hänggi, A. (1998) Evaluation de l'entretien des praires sèches du plateau occidental suisse par le biais de leurs peuplements arachnologiques (Arachnida: Araneae). Revue Suisse de Zoologie, 105, 465-485.

R Development Core Team (2018) R: A language and environment for statistical computing. Version 3.5.0. Available at: https://www.R-project.org (accessed on May 2019).

Rivera-Quiroz, F. A., Garcilazo-Cruz, U., Álvarez-Padilla, F. (2016) Spider cyberdiversity (Araneae: Araneomorphae) in an ecoturistic tropical forest fragment in Xilitla, Mexico. Revista Mexicana de Biodiversidad, 87, 1023-1032.

Russell-Smith, A., Stork, N. E. (1994) Abundance and diversity of spiders from the canopy of tropical rainforests with particular reference to Sulawesi, Indonesia. Journal of Tropical Ecology, 10, 545558.

Rzedowski, J. (1996) Análisis preliminar de la flora vascular de los bosques mesófilos de montaña de México. Acta Botánica Mexicana, 35, 25-44.

Sánchez-Ramos, G., Dirzo, R. (2014) El bosque mesófilo de montaña: un ecosistema amenazado, pp. 109139. In: Gual-Díaz, M., Rendón-Correa, A. (Eds.). Bosques mesófilos de montaña de México: diversidad ecología y manejo. Comisión Nacional para el Conocimiento y Uso de la Biodiversidad, México, Ciudad de México.

Scharff, N., Coddington, J. A., Griswold, C. E., Hormiga, G., Bjorn, P. de P. (2003) When to quit? Estimating spider species richness in a northern European deciduous forest. The Journal of Arachnology, 31, 246-273.

Silva, D. (1992) Observations on the diversity and distribution of the spiders of Peruvian Montane Forests. Memorias Del Museo de Historia Natural UNMSM, 21, 31-37.

Silva, D. (1996) Species composition and community structure of Peruvian rainforest spiders: A case study from a seasonally inundated forest along the Samiria river. Revue Suisse de Zoologie, Volume hors série, 597-610.

Silva, D., Coddington, J. A. (1996) Spiders of Pakitza (Madre de Dios, Peru): species richness and notes on community structure, pp. 253-311. In: Wilson D. E., Sandoval, A. (Eds.). Manu: The biodiversity of southeastern Peru. Smithsonian Institution, USA, Washington.

Sorensen, L. L. (2003) Stratification of the spider fauna in a Tanzanian forest, pp. 92-101. In: Basset, Y., Novotny, V., Miller, S. E., Kitching, R. L. (Eds.). Arthropods of tropical forests: spatio-temporal dynamics and resource use in the canopy. Cambridge University Press, UK, Cambridge 
Sorensen, L. L. (2004) Composition and diversity of the spider fauna in the canopy of a montane forest in Tanzania. Biodiversity and Conservation, 13, 437-452. https://doi.org/10.1023/B:BIOC.0000006510.49496.1e

Sorensen, L. L., Coddington, J. A., Scharff, N. (2002) Inventorying and estimating sub-canopy spider diversity using semi-quantitative sampling methods in an Afromontane forest. Environmental Entomology, 31, 319-330. http://doi.org/10.1603/0046-225X-31.2.319

Ubick, D., Paquin, P., Cushing, P. E., Roth, V. (2017) Spiders of North America: An Identification Manual. American Arachnological Society. USA, Keene, 377 pp.

Williams-Linera, G. (1991) Nota sobre la estructura del estrato arbóreo del bosque mesófilo de montaña en los alrededores del campamento "El Triunfo", Chiapas. Acta Botánica Mexicana, 13, 1-7.

World Spider Catalog (2019) World Spider Catalog. Natural History Museum Bern. Available at: http://wsc.nmbe.ch, version 20.0 (accessed on May 2019).

Yanoviak, S. P., Kragh, G., Nadkarni, N. M. (2003) Spider assemblages in Costa Rican cloud forests: Effects of forest level and forest age. Studies on Neotropical Fauna and Environment, 38 (2), 145154.

http://doi.org/10.1076/snfe.38.2.145.15922 